\title{
First record of Ophiocordyceps dipterigena (Ascomycota: Hypocreales: Ophiocordycipitaceae) infecting adults of Melanagromyza sojae (Diptera: Agromyzidae) in Brazil
}

\author{
Geraldo Salgado-Neto $^{1^{*}} \odot$ Priscila Andre Sanz-Veiga $^{2} \odot$ Marcos André Braz Vaz $^{3}$ \\ 'Departamento de Defesa Fitossanitária, Universidade Federal de Santa Maria (UFSM), 97105-900, Santa Maria, RS, Brasil. E-mail: gsalgado@bol.com.br. \\ *Corresponding author. \\ Universidade Estadual Paulista “Júlio de Mesquita Filho" (UNESP), Botucatu, SP, Brasil. \\ ${ }^{3}$ Instituto de Educação, Agricultura e Ambiente, Universidade Federal do Amazonas (UFAM), 69800-000, Humaitá, AM, Brasil.
}

\begin{abstract}
This note is the first report on the infection of adult stage of Melanagromyza sojae Zehntner, 1900 (Diptera: Agromyzidae) by the entomopathogenic fungus Ophiocordyceps dipterigena (Hypocreales: Ophiocordycipitaceae) (Berk. \& Broome) G. H. Sung, J.M. Sung, Hywel-Jones \& Spatafora, in subtropical Brazil. Entomopathogenic fungi, which attack dipteran insects, are of great scientific and economic importance mainly due to their potential as biological control agents of insect pests. Our findings bring new perspectives on the geographical distribution and host range of Ophiocordyceps dipterigena. We emphasize the need of further studies and research on new biological control agents of agricultural pests such as the soybean stem miner fly.
\end{abstract}

Key words: biological control, entomopathogenic fungi, natural infection, stem miner fly, soybean pests.

Primeiro registro de Ophiocordyceps dipterigena (Ascomycota: Hypocreales: Ophiocordycipitaceae) infectando adultos de Melanagromyza sojae (Diptera: Agromyzidae) no Brasil

RESUMO: Esta nota é o primeiro registro da infecção no estágio adulto de Melanagromyza sojae Zehntner, 1900 (Diptera: Agromyzidae) pelo fungo entomopatogênico Ophiocordyceps dipterigena (Hypocreales: Ophiocordycipitaceae) (Berk \& Broome) G. H. Sung, J.M. Sung, Hywel-Jones \& Spatafora, no Brasil subtropical. Fungos entomopatogênicos, que atacam dípteros, são de importância científica e econômica principalmente devido ao potencial como agentes de controle biológico de pragas de insetos. Este trabalho traz novas perspectivas sobre a distribuição geográfica e variação de hospedeiro de Ophiocordyceps dipterigena. Destacamos a necessidade de ampliar o conhecimento sobre novos agentes de controle biológico de pragas agrícolas como a mosca minadora do caule da soja.

Palavras-chave: controle biológico, fungos entomopatogênicos, infecção natural, mosca minadora do caule, pragas da soja.

Entomopathogenic fungi infect many insect orders as well as arachnids in order to complete part of their development and the dispersion of sexual spores (EVANS, 1982). The fungal families Clavipitaceae, Cordycipitaceae and Ophiocordycipitaceae (Euascomycetes: Hypocreales) include some of the most important and widespread group of entomopathogenic fungi (ARAÚJO \& HUGHES, 2016). As an ecological group, these pathogens have broad geographical and host range and are of great ecological and economic importance, due to their potential as biological control agents and also as a source of medicinal products (FARIA \& WRAIGHT, 2007; SHRESTHA et al., 2010; SOSAGÓMEZ et al., 2010). The genus Ophiocordyceps
Petch, 1931 (Hypocreales: Ophiocordycipitaceae) is a widely distributed group of fungi with approximately 200 described species (CROUS et al., 2004) infecting a wide range of insects from the following orders Coleoptera, Blattaria, Dermaptera, Diptera, Hymenoptera, Hemiptera, Isoptera, Lepidoptera, Mantodea, Orthoptera and Odonata (EVANS, 1982; SUNG et al., 2007; SOSA-GÓMEZ et al., 2010; ARAÚJO \& HUGHES, 2016). However, despite the potential of this fungal group as natural control agents of insect populations, only few entomopathogenic species have been studied in detail. For instance, Ophiochordyceps unilateralis Tulasne \& Tulasne, 1865 core clade sensu (ARAÚJO et al., 2018) that infects Camponotini ants and Ophiochordyceps 
sinensis (Berk, 1843) G.H. Sung, J.M. Sung, HywelJones \& Spatafora, which infects lepidopteran larvae, have been the most studied species (EVANS \& SAMSON, 1984; EVANS et al., 2011; ZHANG et al., 2012; SOBCZAK et al., 2017). Although, other complex of species are still under studied, as it is the case of pathogens of flies (order Diptera).

Dipteran families including Asilidae, Calliphoridae, Muscidae and Tabanidae have also been found parasitized by entomopathogenic fungi (EVANS, 1982; WATSON et at., 1993; STEENBERG et al., 2001; LASTRA et al., 2006; ARAÚJO \& HUGHES, 2016). Despite this, there are few reports in the literature of dipteran insects infected by Ophiocordyceps and little is known about these specific associations (EVANS, 1982; BARBOSA et al., 2016). The family Agromyzidae (Diptera), also called leaf miner flies, comprises a large group of exclusively phytophagous flies. The larval stage parasitizes a wide variety of plant species and infest economically important plants (SPENCER, 1973; BENAVENTE-CORAI et al., 2005). Melanagromyza sojae, also known as the soybean stem-miner, which attacks several species of Fabaceae, has a wide geographic range (Africa, India, Asia and Oceania) and has been considered an important pest of soybean crops (WANG, 1979; TALEKAR, 1989). This species has also been reported in South America, increasing concerns about its potentially negative effects on soybean crops in Brazil (LINK et al., 2009; HIROSE \& MOSCARDI, 2012). In Brazil, agromyzid flies infesting soybean fields were first reported by GASSEN \& SCHNEIDER (1985) in the state of Rio Grande do Sul. LINK et al. (2009) recorded $M$. sojae from five localities in the municipality of São Francisco de Assis, and ARNEMANN et al (2016) identified M. sojae from both Rio Grande do Sul and Santa Catarina states through molecular characterization. Recently, SALGADO-NETO et al. (2017a) collected specimens of M. sojae which were parasitized by parasitoid wasps from different genera within Pteromalidae (Hymenoptera) in the localities of Tupanciretã and Cruz Alta, Rio Grande do Sul State. These findings have brought valuable information about some natural control agents of $M$. sojae that could be used in biological control programs. Global spread and new records of $M$. sojae in soybean fields from South America (GUEDES et al., 2017) highlight the need for further studies on the ecology and management of such a potentially invasive pest. In the present study we aimed to identify the fungus parasitizing adults of $M$. sojae in subtropical Brazil, increasing the information about distribution of natural biological control agents of the soybean stem miner fly.

Melanagromyza sojae adults infected with fungus were collected from off-season soybean plants in 2017. Twenty samples spaced 10 meters apart were taken in two soybean fields located in the

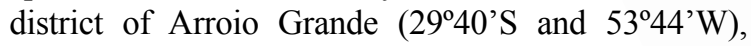
municipality of Santa Maria, Rio Grande do Sul state, Brazil. Flies and fungus stroma were collected in a $60 \mathrm{~mL}$ container and transported to the laboratory of Agropan for species identification. The fungus identity was confirmed through morphological analysis following FREIRE (2015). Despite the fly's advanced state of decomposition, its identification was possible through molecular characterization according to the methodology followed by ARNEMANN et al. (2016). Genomic DNA was extracted from the fly's body by using the ReliaPrep ${ }^{\text {TM }}$ gDNA Tissue Miniprep System kit (Promega). Amplification of the mitochondrial cytochrome oxidase I gene (COI) was performed by using the primers COI-F: 5'-GATTTTTTGGKCAYCCMGAAG-3' and COI-R: 5'-CRAATACRGCTCCTATWGATAAWAC-3' and the 28S rRNA gene amplification by using the primers D2A: 5'-ACAAGTACCGTGAGGGAAAGTTG-3' and D3B: 5'-TCGGAAGGAACCAGCTACTA-3' (DE LEY et al., 1999). The amplified products were purified by precipitation with polyethylene glycol (SCHMITZ \& RIESNER, 2006), subject to sequencing by the chain termination method using the BigDye 3.1 sequencing kit (Applied Biosystems) and analyzed by automated capillary sequencer 3500L (Applied Biosystems). Sequences obtained were then compared to voucher sequences available on the GenBank of the National Center for Biotechnology Information (NCBI) using the Blastn program <http://www.ncbi. nlm.nih.gov $>$. Results confirmed that the infected flies belonged to M. sojae. Four female flies were reported on soybean plant leaves and presented two globular yellow structures protruding from their head that corresponded to the stroma of $O$. dipterigena.

The first record of Diptera infected by $O$. dipterigena in Brazil was reported by SOBESTIANSKY (2005) from Nova Petrópolis in the Rio Grande do Sul State; although, in this case, the host species identification was not possible. Later, FREIRE (2015) collected specimens belonging to $O$. dipterigena complex parasitizing flies of the family Muscidae, Asilidae and Micropezidae in the states of Santa Catarina, Paraná and Amazonas, however whether these specimens are in fact $O$. dipterigena or an unidentified Ophiocordyceps species still remains to be elucidated. BARBOSA et al. (2016) 
reported flies from the family Muscidae infected by $O$. dipterigena in the Minas Gerais state, Brazil. This is the first record in Rio Grande do Sul of the natural action of $O$. dipterigena parasitizing adults of M. sojae (Agromyzidae). Furthermore, this is the first time an adult Agromyzid fly is reported as host of $O$. dipterigena in south Brazil.

Ophiocordycep dipterigena is a natural control agent of Agromyzid flies; and therefore may be of great interest in biological control programs of agricultural pests. To date, most biocontrol products are obtained from few fungi species, none of which have been developed from fungi belonging to Ophiocordyceps. The potential of Ophiocordyceps as a biological control agent of crop pests has been previously explored by SALGADO-NETO et al. (2017b) who tested the pathogenicity of Ophiocordyceps melolonthae (Louis René Tulasne and Charles Tulasne) G.H. Sung, J.M. Sung, Hywel-Jones and Spatafora, 2007 (Hypocreales: Ophiocordycipitaceae) against white grub pests (Coleoptera: Melolonthidae). Despite this, no previous study attempted to test the natural action of Ophiocordyceps fungus against soybean pests. Furthermore, biocontrol agents based of fungi have been used mainly against Coleoptera, Hemiptera and Lepidoptera, but few target dipteran insects (FARIA \& WRAIGHT, 2007). Our finding indicated that $O$. dipterigena might be considered as a potential candidate for the biological control of Agromyzid flies, opening new possibilities for the use of entomopathogenic fungi in biological control programs. Further studies are encouraged to test the effectivity of $O$. dipterigena in reducing the host population, therefore, its potential as a biological control agent of the soybean stem miner.

\section{ACKNOWLEDGMENTS}

We thank Fernando Mafalda Freire, Departamento de Botânica da Universidade Federal de Santa Catarina (UFSC), Brasil for his assistance in confirmation of the entomopathogenic fungi identification and Dr. João Araújo, Department of Biology, Department of Entomology, Penn State University, Pennsylvania, USA by revising and correcting the English language used in this manuscript.

\section{DECLARATION OF CONFLICT OF INTEREST}

The authors declared no potential conflicts of interest with respect to the research, authorship, and/or publication of this article.

\section{REFERENCES}

ARAÚJO, J.P.M.; HUGHES, D.P. Diversity of entomopathogenic fungi: which groups conquered the insect body? In: LOVETT,
B.; ST. LEGER, R.J. Genetics and Molecular Biology of Entomopathogenic Fungi. Advances in Genetics, v.94. Cambridge: Academic Press, 2016. Cap.1, p.1-39. Available from: <http:// www.sciencedirect.com/science/article/pii/S0065266016300013>. Accessed: May 02, 2017. doi: 10.1016/bs.adgen.2016.01.001.

ARAÚJO, J.P.M. et al. Zombie-ant fungi across continents: 15 new species and new combinations within Ophiocordyceps. $I$. Myrmecophilous hirsutelloid species. Studies in Mycology, v.90, p.110-160, 2018. Available from: <https://www.sciencedirect.com/ science/article/pii/S0166061617300593>. Accessed: Feb. 08, 2018. doi: 10.1016/j.simyco.2017.12.002.

ARNEMANN, J.A. et al. Soybean Stem Fly, Melanagromyza sojae (Diptera: Agromyzidae), in the New World: detection of high genetic diversity from soybean fields in Brazil. Genetics and Molecular Research, v.15, n.2, gmr.15028610, 2016. Available from: <http:// www.geneticsmr.com/articles/6653>. Accessed: Sep. 03, 2017. doi: 10.4238/gmr.15028610.

BARBOSA, B.C. et al. Entomopathogenic fungi in Diptera: remarks on range extension and collection records. Boletim do Museu de Biologia Mello Leitão, v.38, n.3, p.257-263, 2016. Available from: $<$ http://www.boletimmbml.net/boletim/index.php/boletim_mbml/ article/view/189>. Accessed: Apr. 07, 2017.

BENAVENT-CORAI, J. et al. Catalogue of the hosts-plants of the world Agromyzidae (Diptera). Bollettino di Zoologia Agraria e di Bachicoltura, v.37, p.1-96, 2005.

CROUS, P. W. et al. MycoBank: an online initiative to launch mycology into the 21st century. Studies in Mycology, v.50, p.12-22, 2004. Available from: $<$ http://www.mycobank.org/>. Accessed: Feb. 09, 2018.

DE LEY, P. et al. Molecular and morphological characterization of two reproductive species with mirror-image anatomy (Nematoda: Cephalobidae). Nematology, v.1, n.6, p.591-612, 1999. Available from: <http://booksandjournals.brillonline.com/ content/journals/10.1163/156854199508559>. Accessed: Apr. 7, 2017. doi: $10.1163 / 156854199508559$.

EVANS, H.C. Entomogenous fungi in tropical forest ecosystems: an appraisal. Ecological Entomology, v.7, p.47-60, 1982. Available from: <http://onlinelibrary.wiley.com/doi/10.1111/j.1365-2311.1982. tb00643.x/abstract>. Accessed: Apr. 7, 2017. doi: 10.1111/j.13652311.1982.tb00643.x.

EVANS, H.C. et al. Ophiocordyceps unilateralis: A keystone species for unraveling ecosystem functioning and biodiversity of fungi in tropical forests? Communicative \& Integrative Biology, v.4, n.5, p.598-602, 2011. Available from: <http://www.tandfonline.com/doi/abs/10.4161/ cib.16721>. Accessed: Apr. 07, 2017. doi: 10.4161/cib.16721.

EVANS, H.C.; SAMSON, R.A. Cordyceps species and their anamorphs pathogenic on ants (Formicidae) in tropical forest ecosystems II. The Camponotus (Formicinae) complex. Transactions of the British Mycological Society, v.82,n.1,p.127-150, 1984. Available from: $<$ http:// www.sciencedirect.com/science/article/pii/S0007153684802193>. Accessed: Apr. 07, 2017. doi: 10.1016/S0007-1536(84)80219-3.

FARIA, M.R.DE.; WRAIGHT, S.P. Mycoinsecticides and mycoacaricides: a comprehensive list with worldwide coverage and international classification of formulation types. Biological Control, v.43, p.237-256, 2007. Available from: <http://www.sciencedirect. com/science/article/pii/S1049964407001843>. Accessed: Apr. 07, 2017. doi: 10.1016/j.biocontrol.2007.08.001. 
FREIRE, F.M. Taxonomia e distribuição de Ophiocordyceps dipterigena (Ophiocordycipitaceae, Hypocreales). 2015. $128 \mathrm{f}$ Dissertação (Mestrado) - Curso de Pós-graduação em Biologia de fungos, algas e plantas, Universidade Federal de Santa Catarina.

GASSEN, D.K.; SCHNEIDER, S. Ocorrência de Melanagromyza sp. (Dip. Agromyzidae) danificando soja no sul do Brasil. In: REUNIÃO DE PESQUISA DA SOJA DA REGIÃO SUL, 13 , 1985, Porto Alegre. Soja: resultados de pesquisa 1984-85. Passo Fundo: EMBRAPA-CNPT, 108-109.

GUEDES, J.V.C. et al. First record of soybean stem fly Melanagromyza sojae (Diptera: Agromyzidae) in Paraguay confirmed by molecular evidence. Genetic Molecular Research, v.16, n.3, gmr16039707, 2017. Available from: <https://www.ncbi.nlm.nih. gov/pubmed/28829894>. Accessed: Sept. 03, 2017. doi: 10.4238/ gmr16039707.

HIROSE, E.; MOSCARDI, F. Insetos de outras regiões do mundo. In: HOFFMANN-CAMPO, C.B. et al. Soja: manejo integrado de insetos e outros artrópodes-praga. Brasília: EMBRAPA, 2012. Cap.7, p.445-492.

LASTRA, C.C.L. et al. Entomophthora ferdinandii (Zygomycetes: Entomophthorales) causing natural infections of Musca domestica (Diptera: Muscidae) in Argentina. Mycopathologia, v.161, n.4, p.251254, 2006. Available from: <https://link.springer.com/article/10.1007/ s11046-005-0248-2>. Accessed: Apr. 07, 2017. doi: 10.1007/s11046005-0248-2.

LINK, D. et al. Mosca da haste da soja: ocorrência e danos, São Francisco de Assis, RS, 2008/09. In: REUNIÃO DE PESQUISA DE SOJA DA REGIÃO SUL, 37., 2009, Porto Alegre, RS. Programas e Resumos. Porto Alegre: UFRGS, 2009. V.37.319p. p.135. Available from: <http://www.ufrgs.br/agronomia/materiais/XXXVIIRPSSul. pdf $>$. Accessed: Apr. 07, 2017.

SALGADO-NETO, G. et al. Syntomopus parisii and Leptomeraporus sp. Parasitizing Melanagromyza sojae in Brazil. Ciência Rural, v.47, n.4, e20160684, 2017a. Available from: <http://www.scielo.br/ scielo.php?script=sci arttext\&pid=S0103-84782017000400204\&ln $\mathrm{g}=$ pt\&nrm=iso $>$. Accessed: Apr. 17, 2017. Epub 06-March-2017. doi: $10.1590 / 0103-8478 \mathrm{cr} 20160684$.

SALGADO-NETO, G. et al. White grub (Coleoptera: Melolonthidae) mortality induced by Ophiocordyceps melolonthae (Ascomycota: Hypocreales: Ophiocordycipitaceae). Ciência Rural, v.47, n.6, e20160788, 2017b. Available from: $<\mathrm{http} / / \mathrm{www}$.scielo.br/scielo.php?script $=\mathrm{sci}$ arttext\&pid $=$ S0103-84782017000600156\&lng=pt\&nrm=iso $>$. Accessed: May 20, 2017. Epub 18-May-2017. doi: 10.1590/0103-8478cr20160788.

SOBCZAK, J. F. et al. The zombie ants parasitized by the fungi Ophiocordyceps camponoti-atricipis (Hypocreales: Ophiocordycipitaceae): new occurrence and natural history. Mycosphere, v.8, n.9, p.1261-1266, 2017. Available from: <http:// www.mycosphere.org/volume-8/issue-9.html\#article1>. Accessed: Feb. 08, 2018. doi: 10.5943/mycosphere/8/9/1.
SCHMITZ, A.; RIESNER, D. Purification of nucleic acids by selective precipitation with polyethylene glycol 6000 . Analytical Biochemistry, v.354, n.2, p.311-313, 2006. Available from: <https://www.ncbi.nlm. nih.gov/pubmed/16725102>. Accessed: Apr. 07, 2017. doi: 10.1016/j. ab.2006.03.014.

SHRESTHA, B. et al. What is the Chinese caterpillar fungus Ophiocordyceps sinensis (Ophiocordycipitaceae)? Mycology, v.1, n.4, p.228-236, 2010. Available from: <http://www.tandfonline. com/doi/full/10.1080/21501203.2010.536791>. Accessed: Apr. 07, 2017. doi: 10.1080/21501203.2010.536791.

SOBESTIANSKY, G. Contribution to a macromycete survey of the States of Rio Grande do Sul and Santa Catarina in Brazil. Brazilian Archives of Biology and Technology, v.48, n.3, p.437-57, 2005. Available from: <http://www.scielo.br/pdf/babt/v48n3/24767.pdf $>$. Accessed: Apr. 07, 2017. doi: 10.1590/S1516-89132005000300015.

SOSA-GÓMEZ, D.R. et al. An overview of arthropod-associated fungi from Argentina and Brazil. Mycopathologia, v.170, n.1, p.61-76, 2010. Available from: $<$ https://link.springer.com/article/10.1007/s11046-0109288-3>. Accessed: Apr. 07, 2017. doi: 10.1007/s11046-010-9288-3.

SPENCER, K.A. Agromyzidae (Diptera) of economic importance. The Hague : Dr. W. Junk B.V., 1973. 9V.

STEENBERG, T. et al. Entomopathogenic fungi in flies associated with pasture cattle in Denmark. Journal of Invertebrate Pathology, v.77, n.3, p.186-197, 2001. Available from: <https://doi.org/10.1006/ jipa.2001.5021>. Accessed: Apr. 07, 2017. doi: 10.1006/jipa.2001.5021.

SUNG, G.H. et al. Phylogenetic classification of Cordyceps and the clavicipitaceous fungi. Studies in Mycology, v.57, p.5-59, 2007. Available from: $<$ http://www.sciencedirect.com/science/article/pii/S0166061614601305>. Accessed: Apr. 07, 2017. doi: 10.3114/sim.2007.57.01.

TALEKAR, N. Characteristics of Melanagromyza sojae (Diptera: Agromyzidae) damage in soybean. Journal of Economic Entomology, v.82, n.2, p.584-588, 1989. Available from: <https://academic.oup.com/ jee/article-abstract/82/2/584/2215107/Characteristics-of-Melanagromyzasojae-Diptera >. Accessed: Apr. 07, 2017. doi: 10.1093/jee/82.2.584.

WANG, C.L. Occurrence and life-history of Melanagromyza sojae on soybean. Journal of Agricultural Research of China, v.28, n.4, p.217-223, 1979

WATSON, D.W. et al. Behavioral fever response of Musca domestica (Diptera: Muscidae) to infection by Entomophthora muscae (Zygomycetes: Entomophthorales). Journal of Invertebrate Pathology, v.61, n.1, p.10-16, 1993. Available from: <http:// www.sciencedirect.com/science/article/pii/S0022201183710037>. Accessed: Apr. 07, 2017. doi: 10.1006/jipa.1993.1003.

ZHANG, Y. et al. Ophiocordyceps sinensis, the flagship fungus of China: terminology, lifestrategy and ecology. Mycology,v.3,n.1,p.2-10,2012.Available from: $<$ http://www.tandfonline.com/doi/full/10.1080/21501203.2011.654354?s rc $=$ recsys $>$. Accessed: Apr. 07, 2017. doi: 10.1080/21501203.2011.654354. 